\title{
BRUTE FORCE ALGORITHM IMPLEMENTATION ON KNOWLEDGE MANAGEMENT SYSTEM OVERCOMING HEAVY METAL OF PB AND CD IN SOIL AT PALM OIL PLANTATION
}

\author{
Ermatita $^{1}$ and Dedik Budianta ${ }^{2}$
}

\begin{abstract}
Disturbances in the production of palm oil is often encountered, including the interruption of heavy metals that are in the soil, plants or oil palm fresh fruit bunches. The existence of these heavy metals can hamper the productivity of oil palm plantations, thus the production of oil palm trees have become not optimal. Therefore, it is necessary counter measures to reduce heavy metals in the soil, plants and fresh fruit bunches on the palm. Analysis of the heavy metal content in the oil palm trees can be in the form of a knowledge base to build a knowledge management system. This research will developed a Knowledge Management System to SECI model and the search for knowledge using Brute Force algorithm. The results of research in the form of search model in knowledge management system with Brute Force algorithm can help build the knowledge to overcome barriers to palm oil production in the form of heavy metals. Reduction of heavy metals in the production of palm oil will reduce the risk of heavy metals in foods derived from processed palm oil.

Key word: Brute Force Algorithm, Knowledge Management System, heavy metals, palm oil, soil.
\end{abstract}

\section{INTRODUCTION}

Increased production of palm oil needs to be done, to improve the economy for the better. Increased production by optimizing the production of palm oil trees are absolutely necessary to support the local economy and the State. The amount of palm oil production is highly dependent on various factors, including the type of soil, seed varieties, climate and the technology applied. In increased production of oil palm trees need to know the various obstacles that can lead to palm productivity becomes low. The presence of heavy metals in soil, plants and fresh fruit bunches of oil palm can hamper productivity.

Each age gives a different production in quantity. This quantity is also greatly affects the production quantity of processed foods derived from oil. A large quantity must also be followed by the quality of the fresh fruit production is high, to avoid negative impact on the consumption of foods derived from palm oil. The quality of this oil crops can tackle by analyzing the metal elements in the soil that are harmful to consumers.

Palm oil plantations also require intensive fertilization. Fertilization intensive as fertilizer P would leave a residue in the form of heavy metals such as $\mathrm{Pb}$ and $\mathrm{Cd}$. The heavy metals through the food chain will enter into fresh fruit production that became CPO, so it will fit into the human body causing various diseases such as kidney disease hazards and diseases lainnya. The heavy metals in the soil need to be overcome by the provision of organic materials.

Knowledge overcome the heavy metals can be included in the knowledge management system, so that in case overcome of problems associated with heavy metals Therefore, the analysis of metals, the weight of which reduce the quality of FFB needs to be done, it is very important to improve the quality of crop production of oil. Analysis of the soil can be either knowledge derived from science and theory, but it also can come from experiences that have been done by someone. Knowledge Management System is a system that can store knowledge [1] [2] [6] [7], so if you see a particular condition can learn the existing knowledge so that it can provide the right solution and quickly, without having to re-do some research. Searches in knowledge management systems require a method or algorithm. Therefore in this study will be used brute force algorithm to search the Knowledge Management System with string matching. Research using Brute Force algorithm has been done by [8] which uses Brute Force algorithm to detect matching pattern picture image. Additionally [9] has conducted research using brute force algorithm and Location Based Services to search a collection of prayer in the prayer. [10] has conducted research string searching algorithm using brute force algorithm that generates

\footnotetext{
${ }^{1}$ Department of Information Systems Faculty of Computer Science, University of Sriwijaya. Indonesia,

${ }^{2}$ Department of Soil Science, Faculty of Agriculture, University of Sriwijaya, Indonesia
} 
proposed algorithm does not preprocess Neither the pattern nor the text to perform searching. These studies carried out for a search on various interests. In this research will be the study of the development of Knowledge Management System that uses Brute Force algorithm to search for knowledge on the SECI Model in Knowledge Management System.

\section{RESEARCH METODOLOGY}

In this study, the analytical framework used is laboratory analysis and assessed with a standard metal element content of $\mathrm{Pb}$ and $\mathrm{Cd}$.Modeling land evaluation results into knowledge, and modeling algorithms search by Brute Force.

Knowledge management system modeling is done by:

a. Kowledge discovery system: the search for knowledge of data and information

1. Perform data collection knowledge

2. modeling string mactching

3. Conduct modeling with Brute Force Algorithm

b. Knowledge capture system: the process of gaining knowledge from explicit or tacit knowledge

c. Knowledge sharing system: the process of distributing knowledge. [5]

Modeling quest for knowledge in Knowledge Management System with Brute Force algorithm.

\section{RESULT AND DISCUSSION}

\subsection{Result of laboratory of PED soil of Brownish Black}

Results of laboratory tests showed the metal content in the soil on the ground around the palm tree. Results of laboratory tests will be saved as a knowledge in the Knowledge Management System to perform analyzes the characteristics of soils that have poor quality for the growth of oil palm trees which can contribute to the quality of palm oil is not good to be harmful to humans consuming food made from palm oil palm tersebut.Kualitas can be donated by the presence of heavy metals in the palm.

Heavy metals are metals that have a very high density. The metal is very dangerous when it came to our bodies through the food chain. In the study observed two types of heavy metals that are widely available in nature is an heavy metal $\mathrm{Cd} \mathrm{Pb}$. Both of these metals can be abundant in the soil due to anthropogenic processes. The threshold values of $\mathrm{Cd}$ in soil that is $3 \mathrm{mg} / \mathrm{kg}$ were $\mathrm{Pb}$ in soils were $12.75 \mathrm{mg} / \mathrm{kg}$.

The results of analysis of soil planted with palm at different age ranges from 0.40 to $2.12 \mathrm{mg} / \mathrm{kg}$, while $\mathrm{Pb}$ ranged from 2.67 to $13.55 \mathrm{mg} / \mathrm{kg}$. Based on the mean value of land planted with palm at different ages do not indicate an abundance of $\mathrm{Cd}$ or $\mathrm{Cd}$ is still below the threshold. While her $\mathrm{Pb}$ have already exceeded the threshold that is on land planted with oil palm in 2000 with a value of $13.55 \mathrm{mg} / \mathrm{kg}$.

Table 1. The content of heavy metals Cadmium $(\mathrm{Cd})$ and lead $(\mathrm{Pb})$ in soil at oil palm trees at different ages.

\begin{tabular}{|l|l|l|l|}
\hline No & Crop year & Cd & Pb \\
\hline 1 & 1989 & $3,27 \pm$ & 2,97 \\
& & 2,01 & 3,05 \\
& & 1,07 & 1,99 \\
\hline & & $\mathbf{2 , 1 2}$ & $\mathbf{2 , 6 7}$ \\
\hline 2 & 1992 & 0,31 & 3,16 \\
& & 1,88 & 5,65 \\
& & 0,68 & 4,53 \\
\hline & & $\mathbf{0 , 9 6}$ & $\mathbf{4 , 4 5}$ \\
\hline 3 & 2000 & 1,65 & 12,86 \\
& & 0,41 & 13,99 \\
& & 1,11 & 13,81 \\
\hline & & $\mathbf{1 , 0 6}$ & $\mathbf{1 3 , 5 5}$ \\
\hline 4 & 2003 & 1,45 & 4,25 \\
& & 1,57 & 3,26 \\
& & 0,93 & 5,29 \\
\hline & & $\mathbf{1 , 3 2}$ & $\mathbf{4 , 2 7}$ \\
\hline 5 & 2006 & 0,29 & 4,53 \\
& & 0,40 & 5,24 \\
& & 0,50 & 3,91 \\
\hline & & $\mathbf{0 , 4 0}$ & $\mathbf{4 , 5 6}$ \\
\hline
\end{tabular}


Results of laboratory tests above will form a knowledge that will be included in the Knowledge Management System. Knowledge management system is done with the first step is to model search system in the knowledge management system with matching string modeling and Brute force algorithm.

\subsection{Modleling of Knowledge Management System.}

\subsubsection{Search Method of String Matching Algorithm Using Brute Force.}

\section{A. Methods Search String Matching}

According to Black11] string is the array of characters (numbers, alphabet, or other characters) is usually presented as a data structure array. String can be a word, phrase, or sentence. While the string matching according to Black [11] is defined as a problem to find the pattern arrangement of the character string in another string or part of the contents of the text.

String matching in Indonesian known as the matching string[12] String matching is the search for a pattern in a text (Ronald L.Rivest et al. 1994).

\subsubsection{Brute Force Algorithm}

Brute Force algorithm is an algorithm to match the pattern with all text between 0 and n-m for the presence of the pattern in the text. In the matching string, there is a text terms and pattern. Text the word searched and matched with the pattern. While the pattern is a word that is entered to match. In detail, the steps taken by this algorithm when matching strings are:

1. Brute Force Algorithm start matching pattern from the beginning of the text.

2. From left to right, these algorithms will match the character-by-character pattern with the character in the corresponding text, until one of the following conditions are met:

a. Characters in the pattern and in the text than not fit.

b. All the characters in the pattern match. Then the algorithm will inform the invention in this position.

3. The algorithm then continues to shift the pattern of one to the right, and repeat step 2 until the pattern at the end of the text.

Here is algorithm Brute Force pseudocode

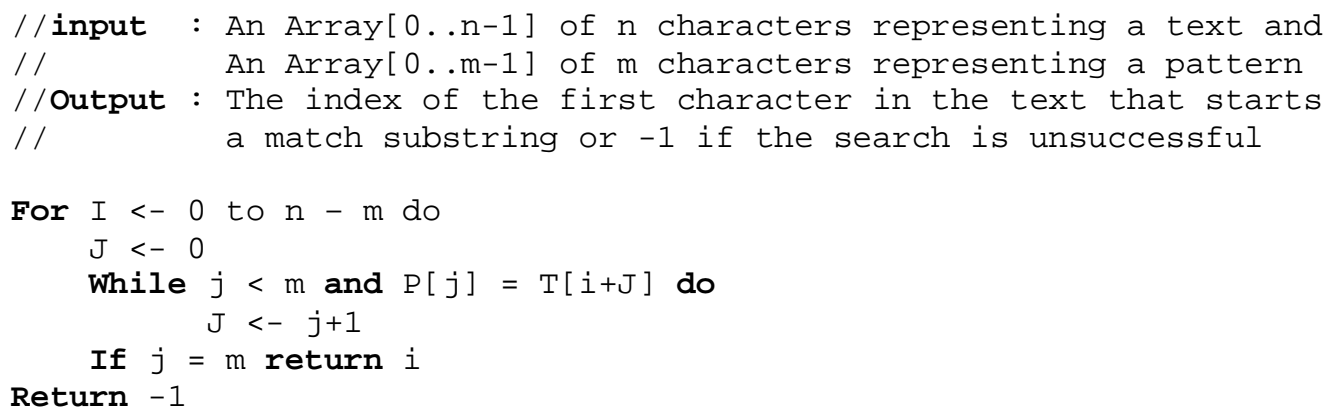

Brute Force Algorithm with Pseudo code above can be used to search for knowledge about the content of heavy metal in the soil, leaves and oil palm fruit bunches. Insights will be stored in the system of knowledge management system. System knowledge management system stores all the knowledge about the characteristics and soil conditions which have been kept informed of the experiences, the results of research. To seek information from existing knowledge in the system of knowledge management system using the method of the String matching and algoritama Brute Force. Here is an example of using Brute Force algorithm for the search pattern in the text:

Searches based on the age ground:

TEXT $=$ AGE OF LAND

PATTERN $=$ LAND Step 1

Specify the text that will be a key in the system, then the system will search for matching text and patern with Brute Force algorithm. As shown below in Table. 2. 
Brute Force Algorithm Implementation On Knowledge Management System Overcoming Heavy Metal Of Pb And Cd In Soil At Palm Oil Plantation

Table 2. Initial step-text search

\begin{tabular}{|c|c|c|c|c|c|c|c|c|c|c|}
\hline \multicolumn{11}{|c|}{$\begin{array}{l}\text { Step Search } \\
\text { Step Search }\end{array}$} \\
\hline Text & $\mathrm{a}$ & g & $\mathrm{e}$ & & & $\mathrm{s}$ & o & $\mathrm{i}$ & 1 & \\
\hline Pattern & $\mathrm{s}$ & o & $\mathrm{i}$ & 1 & & & & & & \\
\hline Index & 1 & 2 & 3 & 4 & 5 & 6 & 7 & 8 & 9 & 10 \\
\hline
\end{tabular}

Table. 2 shows initial step-text search, for search the pattern will shift one step to right toward. Next step shown at Table. 3

Table. 3 Step 1

\begin{tabular}{|l|l|l|l|l|l|l|l|l|l|l|}
\hline \multicolumn{1}{l}{ Step Search } \\
\hline Text & $\mathrm{a}$ & $\mathrm{g}$ & $\mathrm{e}$ & & & $\mathrm{s}$ & $\mathrm{o}$ & $\mathrm{i}$ & 1 & \\
\hline Pattern & & $\mathrm{s}$ & $\mathrm{o}$ & $\mathrm{i}$ & $\mathrm{l}$ & & & & & \\
\hline Index & 1 & 2 & 3 & 4 & 5 & 6 & 7 & 8 & 9 & 10 \\
\hline
\end{tabular}

Results of the search at Table, 3 do not match, then the pattern will shift as much as one step to the right towards index. Table. 4 shown the next step for matching the pattern.

Table .4 Step 2

\begin{tabular}{|l|l|l|l|l|l|l|l|l|l|l|}
\hline \multicolumn{1}{|l|}{ Step Search } \\
\hline Text & a & g & e & & & s & o & i & 1 & \\
\hline Pattern & & & s & o & i & 1 & & & & \\
\hline Index & 1 & 2 & 3 & 4 & 5 & 6 & 7 & 8 & 9 & 10 \\
\hline
\end{tabular}

The next step is to shift one step further as Table. 5

Table. 5 Searches

\begin{tabular}{|l|l|l|l|l|l|l|l|l|l|l|}
\hline \multicolumn{1}{|l|}{ Step search } \\
\hline Text & a & g & e & & & s & o & i & 1 & \\
\hline Pattern & & & & s & o & i & 1 & & & \\
\hline Index & 1 & 2 & 3 & 4 & 5 & 6 & 7 & 8 & 9 & 10 \\
\hline
\end{tabular}

If the search is not yet match the text and are in search of patterns, then the shifting of patterns as much as one step to the right towards index Step 3.

Table. 6 Search Information

\begin{tabular}{|l|l|l|l|l|l|l|l|l|l|l|}
\hline \multicolumn{1}{|l|}{ Step search } \\
\hline Text & a & g & e & & & s & o & i & 1 & \\
\hline Pattern & & & & & s & o & i & 1 & & \\
\hline Index & 1 & 2 & 3 & 4 & 5 & 6 & 7 & 8 & 9 & 10 \\
\hline
\end{tabular}


Search in step 4 is shown in Table. 6 do not match between text and patern, then the shift pattern is then performed by one step to the right towards the index. The next step is shown at Table. 7

Table.7. Search Information

\begin{tabular}{|l|l|l|l|l|l|l|l|l|l|l|}
\hline \multicolumn{1}{|l|}{ Step serach } \\
\hline Text & a & g & e & & & s & o & i & 1 & \\
\hline Pattern & & & & & & s & o & i & 1 & \\
\hline Index & 1 & 2 & 3 & 4 & 5 & 6 & 7 & 8 & 9 & 10 \\
\hline
\end{tabular}

Table. 7 shows do not match text and pattern, the shear pattern as much as one step to the right towards index In step 6 of a match is found and the text in the search pattern. For those reasons, the termination stops at index 10 .

Knowledge discovery search over a system which is in the process of Knowledge Management to seek the knowledge of the data and information contained in the database, or look for connectivity of data and information with other data and information. The results of the modeling above the Brute Force method text matches with the information obtained in the search. The data found in files that are already stored in the system knowledge system with SECI models.

Maching String methods and algorithms Brute force is a method that can be implemented to build the system Knowledge management system with a certain pattern. Pattern (patern) knowledge to do a search with the Brute Force method so as to facilitate the search for solutions to problems. By building knowledge management system modeling can help in the search for information related to the quality of palm oil which is influenced by the content of heavy metals in the soil. These insights are useful for sharing knowledge for those who are concerned with the quality of palm oil as an ingredient for the manufacture of food, so the danger of heavy metal in the palm oil can be tackled.

\section{CONCLUSION}

String matching methods and Brute force algorithm is a method that can be implemented to developed the system Knowledge management system with a certain pattern. Pattern of knowledge to do a search through Brute Force method so as to facilitate the search for solutions to problems. By developing knowledge management system modelling can help in the search for information related to the quality of palm oil which is influenced by the content of heavy metals in the soil. These insights are useful for sharing knowledge for those who are concerned with the quality of palm oil as an ingredient for the manufacture of food, so the danger of heavy metal in the palm oil can be tackled.

\section{REFERENCES}

[1] All-Hawamdeh. Knowledge Management, cultivating Knowledge professionals. Oxford: Chandos Publishing (Oxford) Limited. 2003.

[2] Bock, W. Knowledge Management 101. Intranet Corner. 2002

[3] Teoh, C.H . Key Sustainability Issues in the Palm Oil Sector, A Discussion Paper for Multi-Stakeholders Consultations" (commissioned by the World Bank Group). 2010.

[4] Dinas Perkebunan Provinsi Sumatera Selatan. Menuju Satu Angka Statistik Perkebunan secara Nasional. Palembang. 2011

[5] Fernandez, I.B., \&Sabherwal, R. (2010) Knowledge Management : system and processes. New York: M.E. Sharper, Inc.

[6] Nonaka, Ikujiro and Takeuchi, Hirotaka (1995). The Knowledge-Creating Company: How Japanese Companies Create the Dynamics of Innovation. Oxford: Oxford University Press.

[7] Tiwana, A. (1999). The Knowledge Management Toolkit: practical techniques for building a knowledge management system. London: Prentice-Hall, Inc.

[8] Wicaksana, A.P. 2013, Algoritma Brute Force dalam Pattern Matching pada Aplikasi Pendeteksian Potongan Citra, Makalah IF3051 Strategi Algoritma Sem. I Tahun 2012/2013. Available at http://marvinproject.sourceforge.net/download/Makalah-IF3051-2012025.pdf. access at August $3^{\text {th }} 2016$

[9] Fenty E.M.A, Hanifa. H, Riyanto. H. Implementasi Algoritma Brute Force Dan Fitur Location Based Service (LBS) Pada Aplikasi Kumpulan Doa Harian Berbasis Android. Jurnal Pseudocode. Vol 1, No 2 (2014). Program studi Teknik Informatika. Fakultas Teknik. Universitas Bengkulu. http://ejournal.unib.ac.id/index.php/pseudocode/article/view/143. access at August $3^{\text {th }} 2016$

[10] Rawan Ali Abdeen. An Algorithm for String Searching Based on Brute-Force Algorithm . IJCSNS International Journal of Computer Science and Network Security, VOL.11 No.7, July 2011.pp 24-27. http://paper.ijcsns.org/07_book/201107/20110704.pdf. access at July $21^{\text {th }} 2016$

[11] Syaroni. M dan Munir. Pencocokan String Berdasarkan Kemiiripan Ucapan (Phonetic String Matching) dalam Bahasa Inggris. Seminar Nasional Aplikasi Teknologi Informasi 2005 (SNATI 2005).Departemen Teknik Informatika Fakultas Teknologi Industri . Institut Teknologi Bandung (ITB). ISBN: 979-756-061-6

[12] Hadiati, D, Penerapan Algoritma String matching pada permainan Word Search Puzzle. Makalah IF 2251 Strategi Algoritmik.2007. Program Studi Informatika, Sekolah Teknik Elektro dan Informatika, Institut Teknologi Bandung http://informatika.stei.itb.ac.id/ rinaldi.munir/Stmik/2006-2007/Makalah_2007/MakalahSTMIK2007-012.pdf 